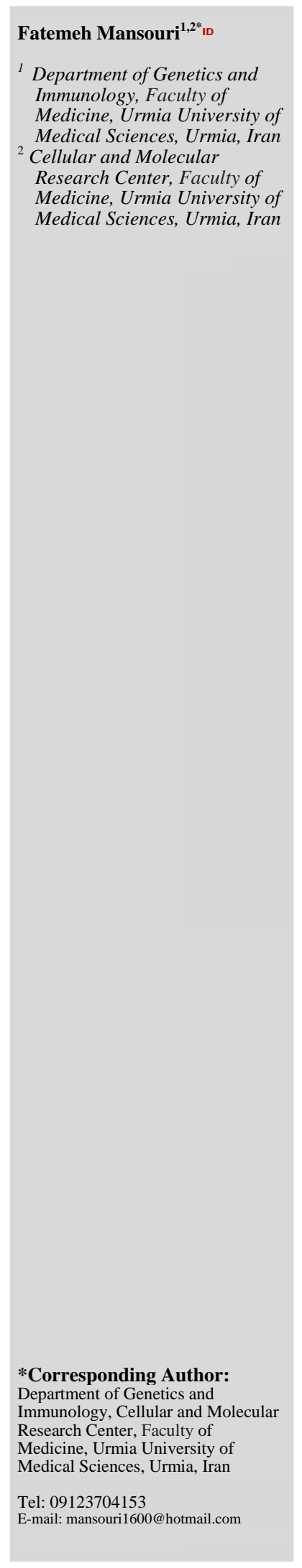

\title{
A Review of Stem Cell Technology
}

Received: 29 Nov. 2016 ; Accepted: 31 Dec. 2017

\section{Abstract}

Stem cells as natural cells exist in embryonic and adult tissues. Recent studies have begun to prove the strong and powerful role of stem cells in the field of treatment. Stem cells have the potential for self-renewal and differentiation into specific types of somatic cells. Their ability to produce new cells in medicine, drug discovery, cell therapy and research is very important. In the past decades, many efforts have been made to find safe, low-cost methods and progress stem cell culture. The purpose of this review article is to: 1) explain the application of stem cells in medicine, drug discovery, modeling of disease and toxicology studies. 2) A summary of recent advances in stem cell technology, the advantages and disadvantages of the most commonly used culture methods.

The result of this discussion shows that the use of new culture methods can be effective in the optimal use of stem cells.

Keywords: Stem cells Technology, Medicine, Drug discovery 


\section{مرورى بر تكنولوزى سلولهاى بنيادى}

تاريخ دريافت مقاله: 90/9/9 ؛ تاريخ يذيرش:•/1/99/19

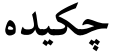

مقدمه: سلولهاى بنيادى به عنوان سلولهاى طبيعى در بافتهاى جنينى و بالغين وجود دارنسـ. مطالعـات اخيـر در جهـت

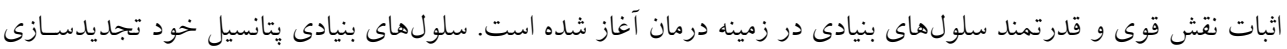

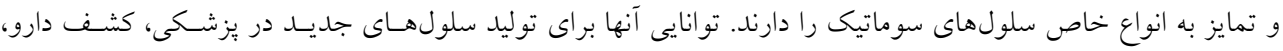

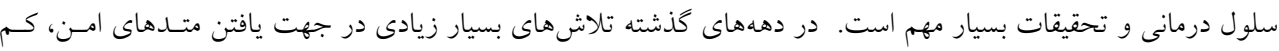

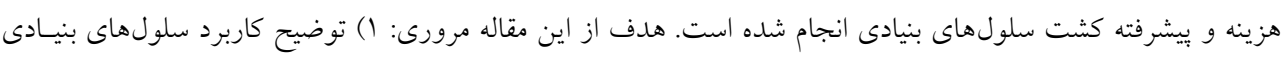

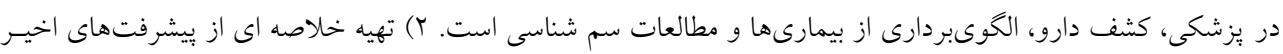

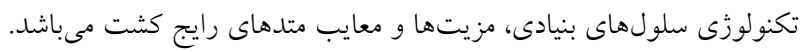

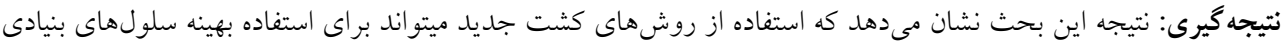
موثر باشد. كلمات كليدى: تكنولوزى سلولهاى بنيادى، يزشكى، كشف دارو

فاطمه منصورى ID I I

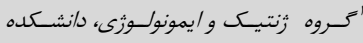

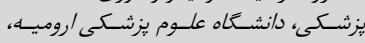

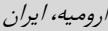

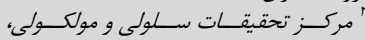

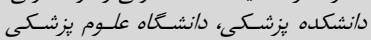

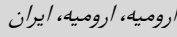




$$
\text { فقط سلولهاى خونى را بسازند. }
$$

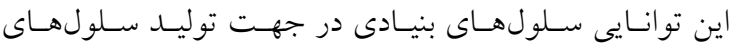

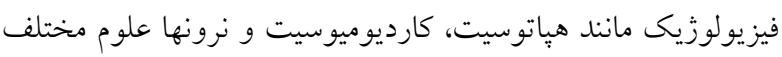
يز شكى را تحريك به مطالعه براى تحقيق در اين زمينه كرده اسـت فئ.

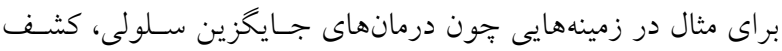

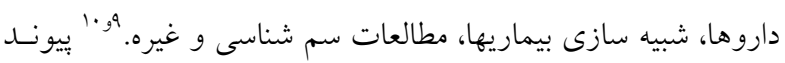
مغز استخوان كه جهل سال است انجام مىشود از جمله ايـن كارهـا مى باشد. مغن استخوان كئ

سلولهاى بنيادى خونى يا (Hematopoietic Stem Cell=HSC) به ميزان كمى در خون وجود دارند اما توانايى باز سازى يكى سيستم خونى را به طور كامل دارند. اخيـرا سـلولهــاى بنيـادى در درمـان برخى بيمارى ها استفاده مى شوند. مثلا از سلولهــاى بنيـادى نـرون جنينى براى درمان آسيبهاى نخاعى و يا سلولهاى بنيادى نـورون

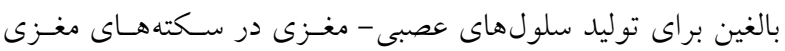

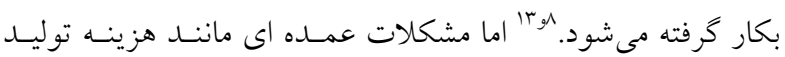

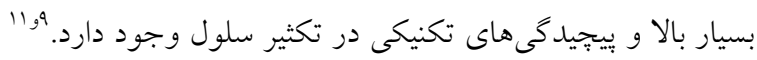

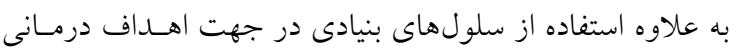
خطر سلولهاى غير متمايز شده و ايجاد سلول سرطانى را به همـراه

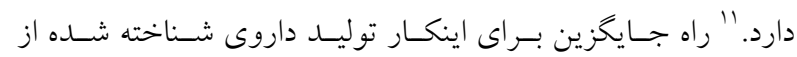

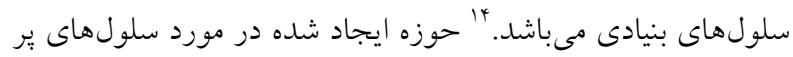

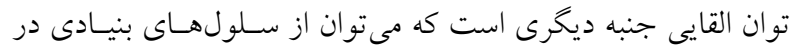

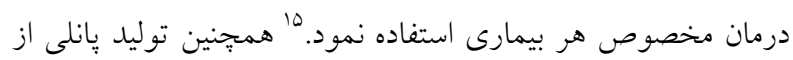

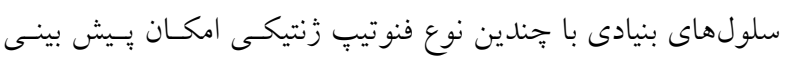

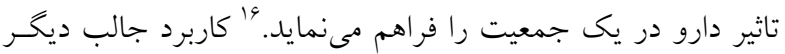
در مورد سلولهاى بنيادى توليد داروهايى از سلولهاى بنيادى است

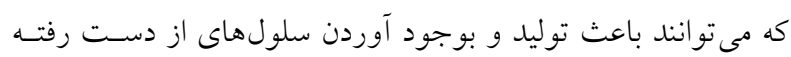

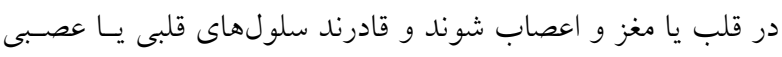

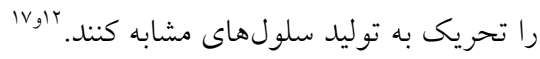

\section{انواع سلولهاى بنيادى}

سلولهاى بنيادى يرتوان مهمترين سلولهاى بنيادى هستـند كـهـ

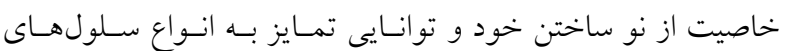

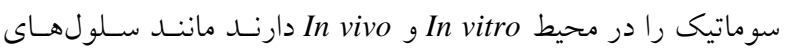

سلولهاى بنيادى سلولهاى طبيعى هســند كـه قابليـت تكثيــر،

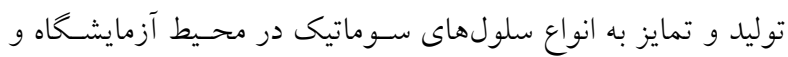

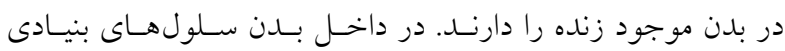
مختلفى وجود دارد و در اركانيسمهاى بـالغ در هموستاز و وترميم

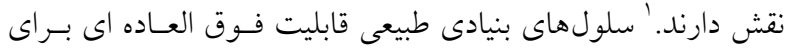

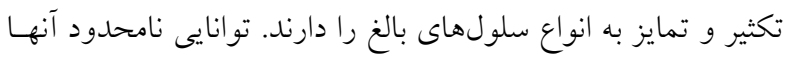

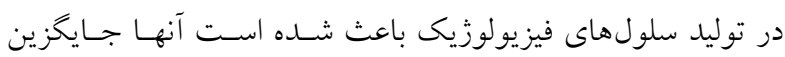

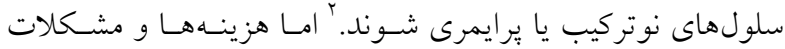
تكنيكى و نحوه هدايت آنها به سلولهاى مورد نظر مشـكلاتى دارد

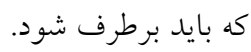

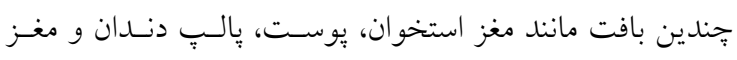

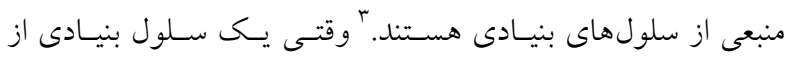
جايخاه اصلى خود (Nich) برداشته مى شود، شروع به تمايز مى كنــ.

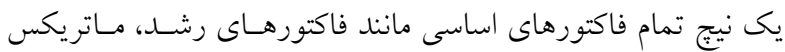

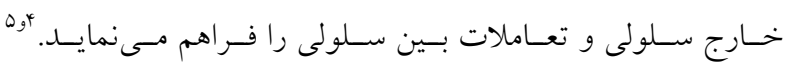

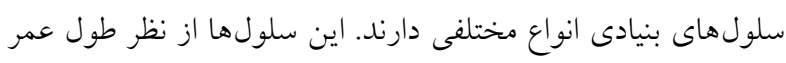

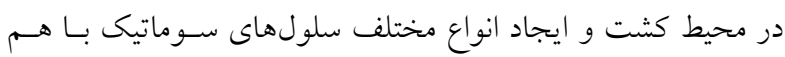
فرق دارند. "سلولهاى بنيادى يا استم سلها در مراحل كشف دارو،

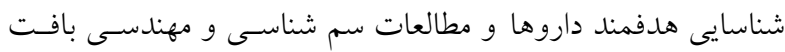
مى تواند انقلاب عظيمى ايجاد كنند.

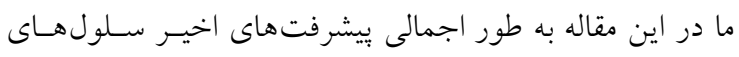

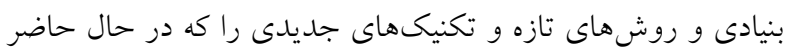

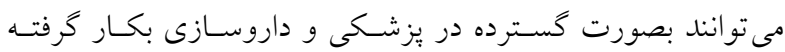
شوند بررسى كرده ايم.

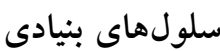

مهمترين سلولهاى بنيـادى يرتسوان (pluripotent)، سـلولهـاى ئس جنينى يا سلولهاى القايى هستند كه قابليت توليد خودشان و انسواع

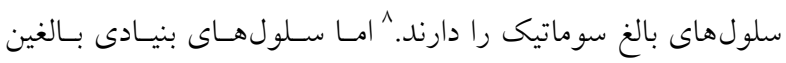

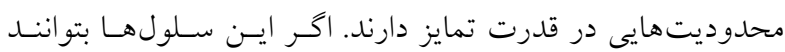

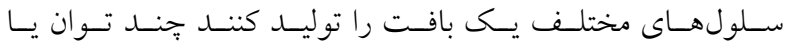
هستند، براى مثال سلولهـاى هماتويويتيـك قادرنـــ 
توده سلولهاى داخلى جدا مى شود كه شامل ·r عدد سـلول اسـت

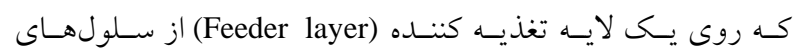
فيبروبلاسـتى كــه تقسـيمات ميتـوزى آنهـا منـع شـــه كشـت داده مىشوند. "19 يس از يك تا دو هفته، رشد سلولها بيشـتر شــده و بــهـ

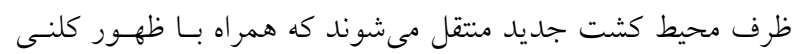

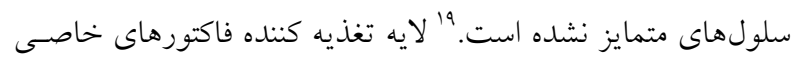

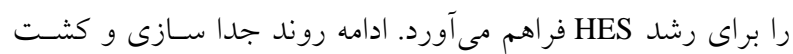
اين سلولها با جند روش امكان يذير است (شكل (1).

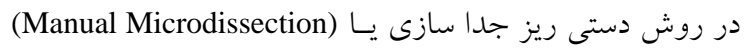
از ميكروييبت هاى ظريف مخصوص براى جــا سـازى كلنسى هـاى HES

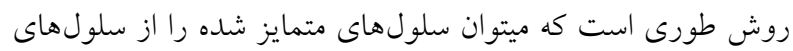
متمايز نشده جدا كرد. البته اين روش بسيار وقت گير است. روش ديخر روش آنزيمى است كه سريعتر از روش قبلى انجـام

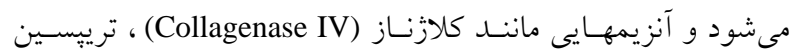

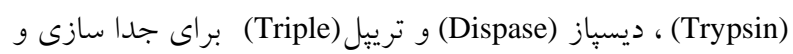

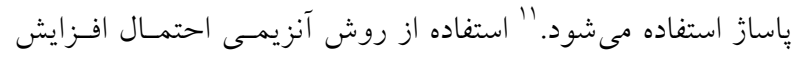

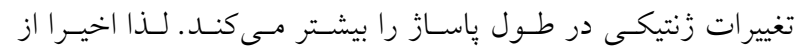

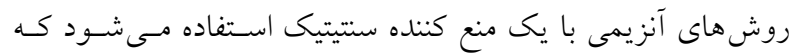

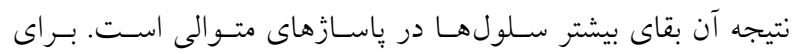

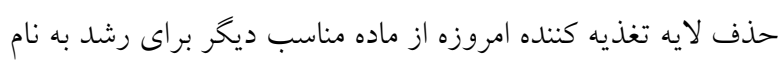
Matrigel
خونى، عصبى، يانكراس و قلب.

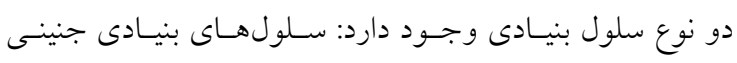
يا (Embryonic Stem Cells=ESC)كه از سـلولهــاى لايسه داخلـى توده جنين قبل از لانه گزينى گرفته شده است و در ابتدا از موش و

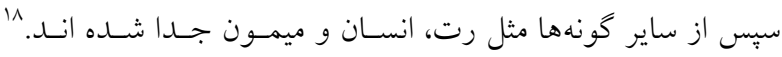
سلولهاى بنيادى جنينى مشتق شده از انسان به عنـوان Pluripotent

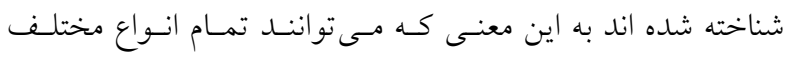

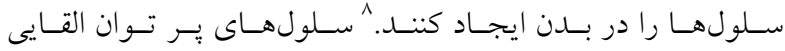
با برنامه ريزى مجدد روى (Induced Pluripotent Stem Cell=IPS) سلولهاى سوماتيك بالغين و تبـــيلشـان بـه اسـتم سـلهـا ايجــاد

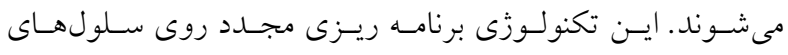
سوماتيك، ابتدا در موش و سبس در سلولهاى انسانى انجـام شـده است."19 اين سلولها تعداد كمى دارند و اغلب در قسـمتهاى عمقىى بافت وجود دارند كه بدين طريق شناسايى، جداسازى و رشـد آنهـا در محيط آزمايشخاهى قدرى مشكل است.

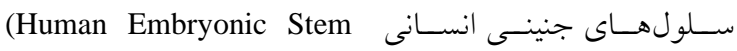

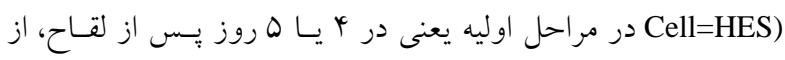

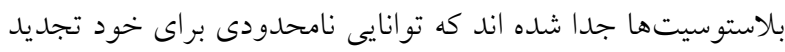

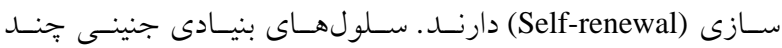
توان(Multipotent) هستند و از بافت هاى جنينى يا عروق بنــ نـاف بلدست مى آيند.

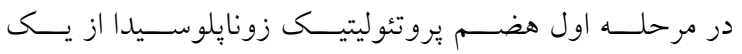
بلاستوسيت براى حذف تروفو اكتودرم با آنتى بادى انجام مىشـود و

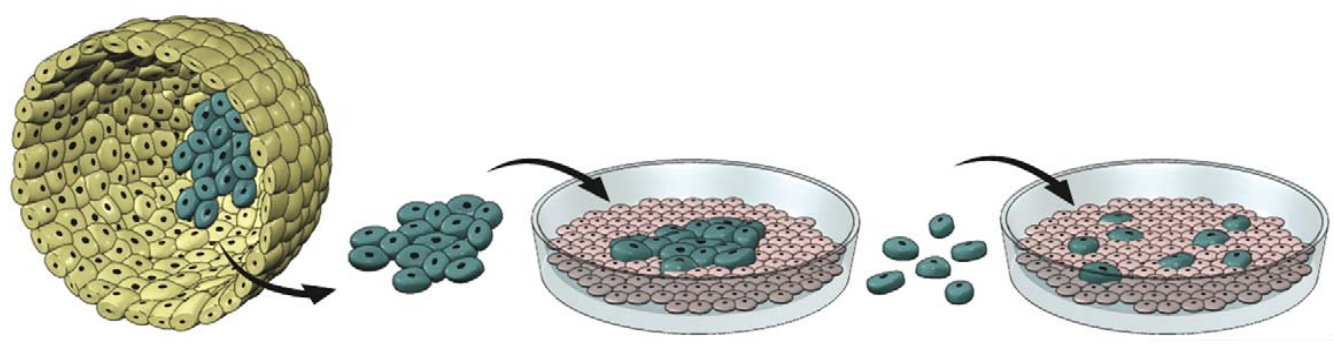

شكل ا: جدا سازى سلولهاى بنيادى جنينى انسان. از يكى بلاستوسيت انسانى در روزهاى بنجم تا هفتم بـ از لقاح توده سلولهاى داخلى جدا شـده و روى يكى لايه تغذيه كننده از سلولهاى فيبروبلاستى كشت داده مىشوند. پِ از يكى تا دو هفته، رشد سلولها بيشتر شده و بـه ظـرف محسيط كشـت جديــ منتقـل

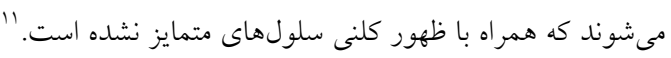




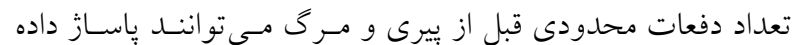
شوند." همجنين تنوع در دهندهاى سلولى باعث بروز نتسايج غيـر

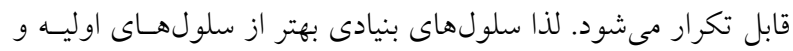
نوتركيب عمل مى كنند جرا كه خيلى زياد تكثير مى يابند و مى توانند

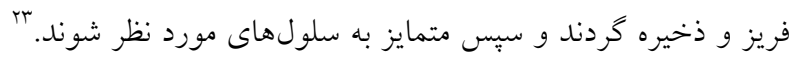
بعلاوه IPS مى توانند به سلولهــاى سـوماتيك اختصاصى بيمـارى

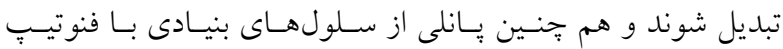

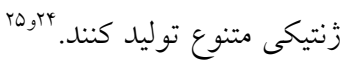

بصورت كاربردى دكتر Pfizer سلولهاى بنيادى جنينى موش را

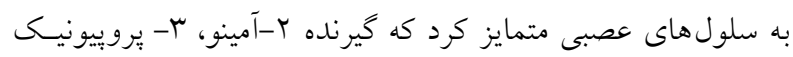

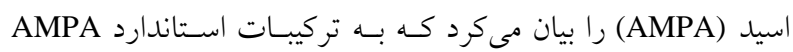
ياسخ مناسبى داشت. بعدها كاربرد انتخاب يكى كلـون سـلولى بكـار

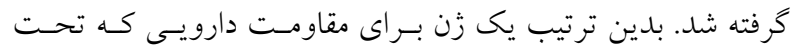

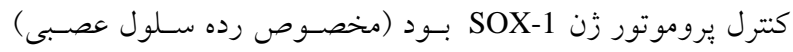
وارد سلول شد تا بتواند در طول تمايز سلولهاى بنيادى جنينسى، از از

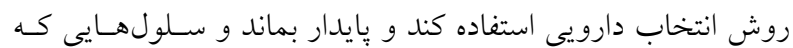

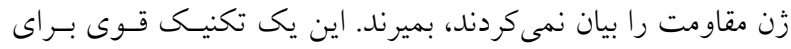

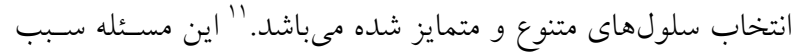

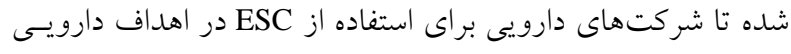
با دانشخاهها تبادلات علمى داشته باشند."

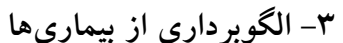

سلول هاى بنيادى مى تو انند به سلول هاى سـوماتيك اختصاصى بيمارى تبديل شوند كه در مورد نحوه تاثير دارو در آن بيمارى مورد

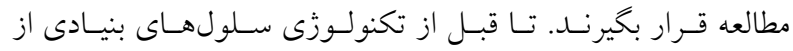

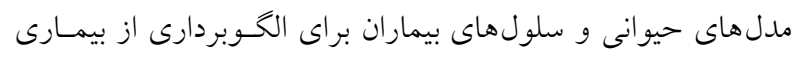

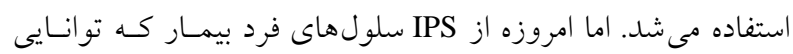
توليـــ ردهــاى سـلولى اختصاصسى مختلـف و تبـــيل بـه سـلول سوماتيك را دارند استفاده مى شود. مثلا در سندرم مادرزادى هاى بلند و نامنظم ضربان قلب كه موتاسيون در كانال بِتاسيم دارند، ايــن سلولهاى IPS به سلولهاى عملكردى قلبى متمايز مى شود تا علت

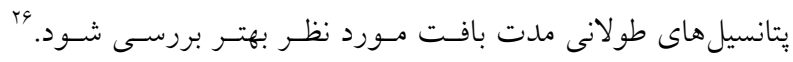

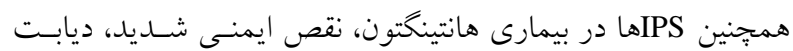
جوانـان، بيماريهـاى قلبس -عروقسى و بيمـارى آتروفسى نخـاعى -
ها بسيارى از خصوصيات SES إ رارند به علاوه مشخص شده است كـه برنامـهـ ريـزى مجــد سـلولهـاى سـوماتيك باعـث

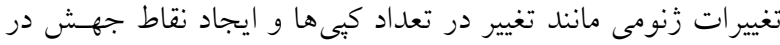

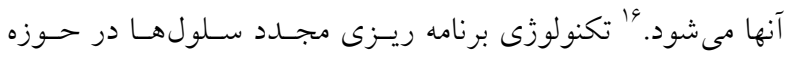
درمان تخصصى بيماران و توانيى براى توليد سلولهاى بنيادى ويزه

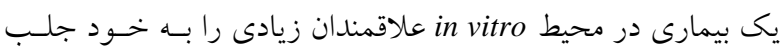

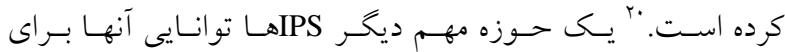
دستكارى هاى زُنتيكى ثابت و مستقل شونده به نسل هاى بعدى براى مطالعات زنها است.

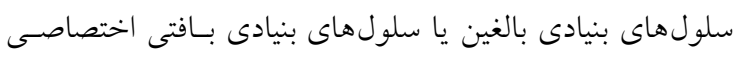

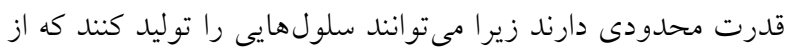

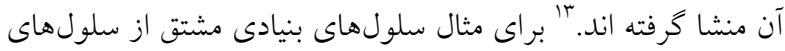
عصبى به سلولهاى آستروسيت، اليخودندريسيت يا نورونها متمايز

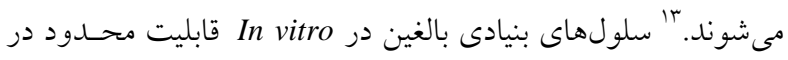

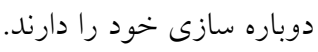

\section{كاربرد سلولهاى بنيادى در كشف داروها}

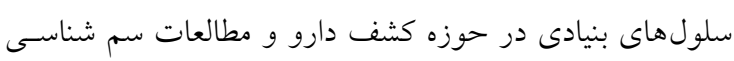
كاربرد دارند.

\section{1 - شناخت هدفمند}

به واسطه تمايز سـلولهــاى بنيـادى بـهـ يـك گـروه خاصسى از

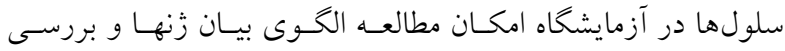
مكانيسم مولكولى زنها و امكان شناسايى يـروتئينهـاى احتمـالى در

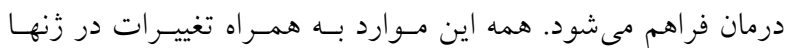
مطالعات را كَسترده تر كرده است و استفاده از روشهــاى مولكسولى هرئي به تشخيص دقيق تر و بهتر بيمارىها منجر شده اسـت و تشـخيص

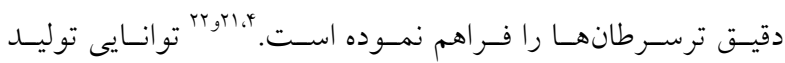

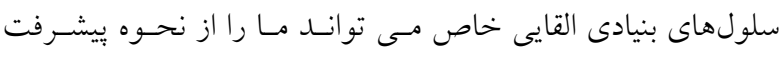
بيمارى و پِاتولوزى آن بيمارى مطلع سازد. r- بر بالكرى در مقياس زياد

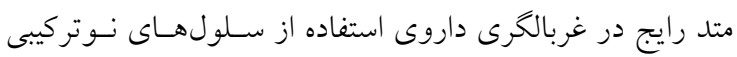
Primary cells است كه داراى زن خاصى هستند سلولهاى اوليه مى تواند براى اين منظور مفيد باشند، اما خيلى كم يافت مى دشوند و 
نشده يا به مقدار كافى شناخته نشده است." روش ديخر توسعه و رشد سلولهاى بنيادى بالغين يا سلولهاى

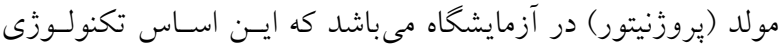
آزمايشگاهها (Progenitor lab) مى باشد كه باعـث بـه وجــود آمــدن

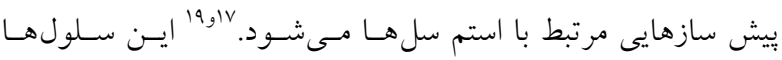

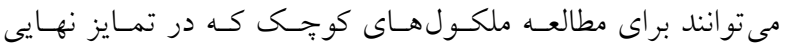

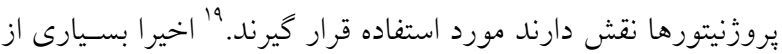
مر اكز بدنبال كشف سلولهاى كوجــى دارويسى هستـند كـه باعـث

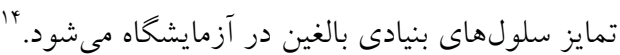
مهمترين ضرورت براى بكار گرفتن سلولهاى بنيادى قابليت و قدرت تمايز آنها به سلولهاى مورد نظر و قابل اعتماد بودن آنها و

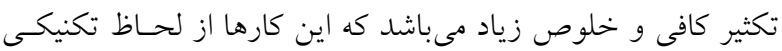
ساده نيستند و براى همين علت سـلولهــاى بنيـادى در داروسـازى رئر

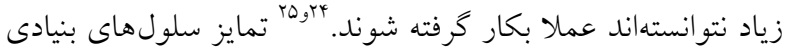
به سلولهاى بالغ نياز به مراحل كشت متوالى و اضافه كردن مـاواوم

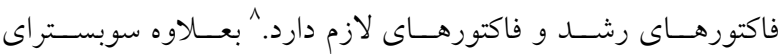

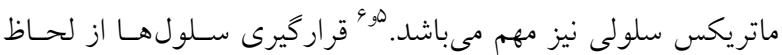
فضايى و موقعيت سـلولهـا در محسيط باعـث تـاثيرات زيـادى در سرنوشت آنها شود و كنترل تمام اين مسايل مستلزم صرف وقت و و ولى

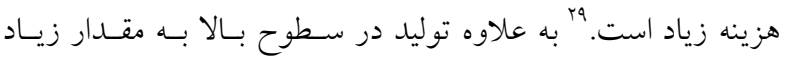
نيازمند شرايط استاندارد است يعنسى محيطى كـه احتيـاج بـه سـرم نداشته و نياز به تغذيه كننده سلولى نباشد.ه

\section{مطالعات سم شناسى}

•r درصد همه داروهاى تحت آزمايشات بالينى در مراحل اوليه. كنار گذاشته مىشود كه عمدتا بدليل اثرات سمى روى كبد يا قلـب

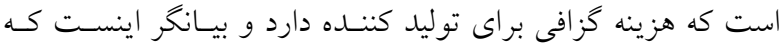

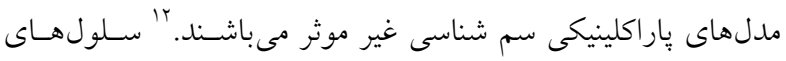

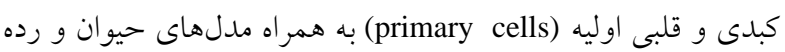
سلولهاى نوتركيب براى تسـتهــاى ســم شـناختى در آزمايشــاه

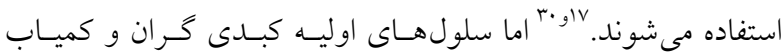

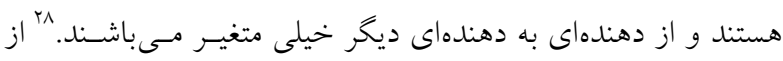
طرفى رده سلولهاى نوتركيب و مدل حيوانى نمى توانــــ مثـل كبــ

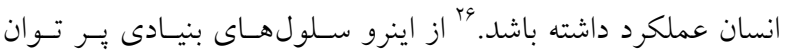

عضـالنى(Spinal Muscular Atrophy=SMA) مــورد بررسسى قـرار كر فته است. يكى از مشكلات اين روش اين است كه براى مثال در بيمـارى

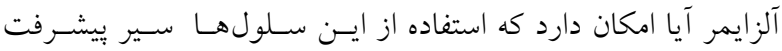
بيمارى را كندتر كند و آيا آنهـا ميتوانـــد در جهـت سـلولى متمـايز شوند كه عملكرد طبيعى سلولهاى نرمال را در داخل بافت انجـام دهد؟ در نتيجه فعلا بيماريهاى كه فقط يكى نـوع خـاص سـلولى را

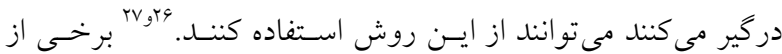
مراكز بر روى استفاده از IPS هاى اختصاصسى در كشـف داروهـا و توليد ينلى از IPS براى بررسسى مشكلات نورولـوزيكى، بيمـارى عصبى، قلبى و بِاركينسون فعاليت مى كنند." ץ- باروهاى تحريك كنتده تكثير و رشد علاوه از كاربرد سلولهاى بنيادى در غربـالخرى دارويسى، آنهـا داراى يتانسيل خوبى براى توليد داروهاى جديد و فاكتورهايى براى تحريك داخل سلولى براى تكثير بافت در جهت جبران سـلولهـاى

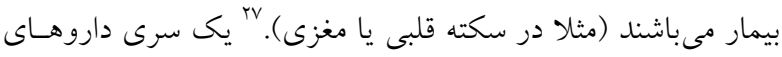

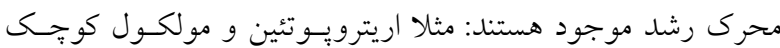

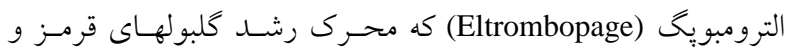
يلاكت ها از ردههاى همويوئيتيك هستند. الترومبويخ يك اخونيست كيرنده ترومبويـوئيتين (TPO) اسـت كـه بـا اسـتفاده از غربـالكرى سـلولى در يـك رده سـلولى نوتركيـب كـه كيرنسـه TPO را بيـان مى كردند كشف شد. بررسى اين عوامل از طريق شناخت كيرندهـــا

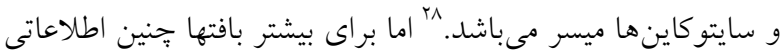
در دسترس نيست. يكى راه ديخر اينست كه خود سلولهاى بنيـادى و سـلولهـاى لئل مولد (Progenitor cells) روى خودشان تاثير بحذارند تا تحريك بـه

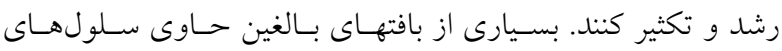

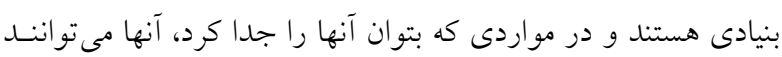
وسيله خوبى براى غربالكرى دارويى و محركهـاى رشــ و تكثيـر باشند." براى مثال سلولهاى بنيادى مزانشيمال مى توانند هدف بـ بـيش از هزار نوع ملكــول قـرار بخيرنــــــهـ در جهـت اسـتخوان سـازى تحريـك شـوند. بــراى اسـتخوان سـازى تركيبـات وب كانسهاى در

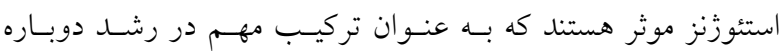

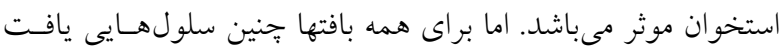




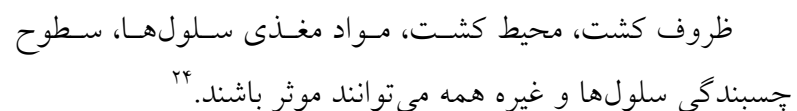

\section{سيستمهاى ميكروارى و ميكروفلوئيديك كشت}

يك روش ديخر بررسى كشت سلولى با استفاده از تكنيكهـاى

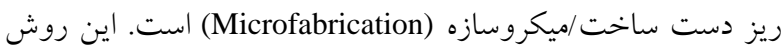
باعث مىشود كه بسيارى از آزمايشها بصورت موازى به جلسو رود و در هزينه صرفه جويى شده و امكـان بررسسى رفتـار يـك سـلول

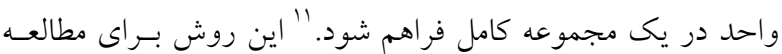
تاثيرات متقابل بين ارتباط سلولهاى بنيادى و فاكتورهاى سلولى در محسيطهـاى بسـيار كوجـك بـه كمـى يـك ربـات در بليـتهـاى

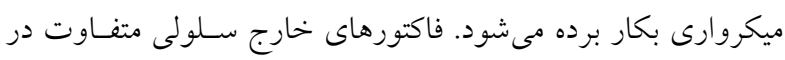
تركيبات مختلف به ميكروارىها وارد مسىشـود و مطالعسه همزمـان

دهها يا صدهاى محيط كشت را قادر مى سازد. بr. تكنولوزى ميكروفلوئيدى باعث تسريع تغييرات در محيط كشت مىشوند كه اين تغييرات در زمانى كه ما مى خواهيم انجام مى كردد. همجنين مطالعه امبريونيك سلولها و انجام ميكرفلوئيدها در كشـت

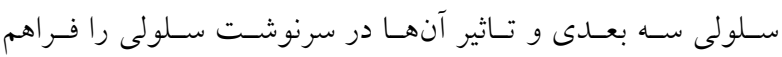
مى كند.

\section{كشت سلولى تر كيبى (Combinatorial)}

خصوصيت تمايز سلولهاى بنيادى به طور متوالى باعث ايجـاد

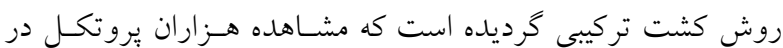

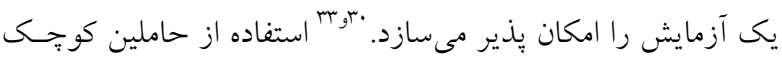
سبب تكامـل ايسن روش شـــه اسـت. سـلولهـاى (Microcarrier) بنيادى روى ميكرو حامـلهـاى بيــى در روى جنـــ محسيط تمـايز

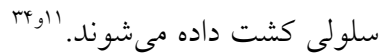

يروسه متوالى كشت و ياساز يا به عبارتى تقسيم بندى استخرى ( باعث بررسى مرحلـه بـه مرحلـه همــه انـواع تركيبـات (split-pool

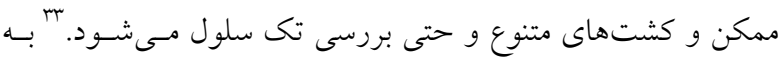

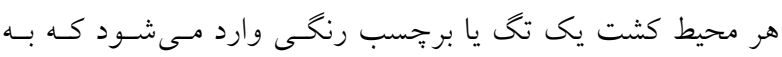

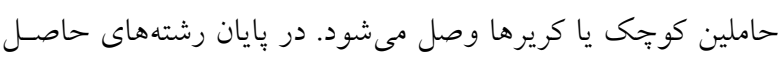
سلولهاى تمايز يافته بوسيله روشهاى غربالكرى مثل رنخ آميـزى ترى
مسى توانـــد منبـع غيرمحسـدودى بــراى سـلولهــاى كبــى و قلبـى

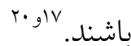

ها جايخاه ويزهاى دارند جِون به آسانى از هر كس مىتوانند كر فته شوند و سيستم خوبى براى توليد سلولهايى هستند كه بتـوان

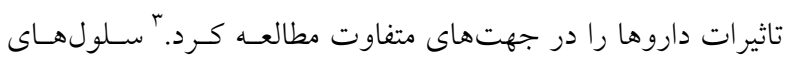
بنيادى متمايز شده به هياتوسيت ها بسيار توانمند هسـتند، زيـرا مسى

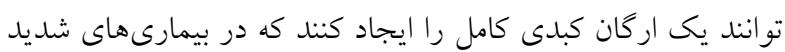
كبدى مورد استفاده قرار كيـرد و از طرفى بـــاى كشـف داروهـاى جديد در جهت مطالعات توكسيسيتى و متابوليسـمى مـورد اسـتفاده

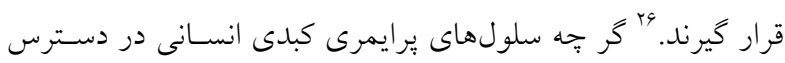

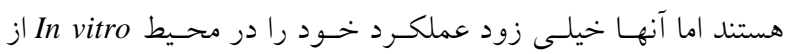
دست ميدهند و غير قابل استفاده مى شوند كـه ايسن مسـئله يكـى از محدوديت هاى آنهاست. 'بردهاى سلولى هياتوسـيت در دسـترس،

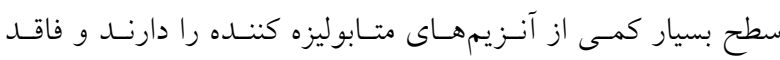

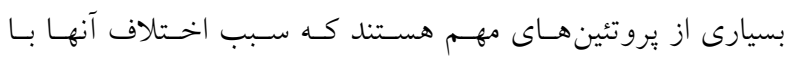

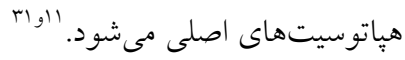

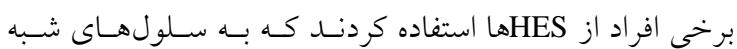
هياتوسيت تبديل مىشوند كه فنوتييى شبيه هياتوسيت دارد. اما ايسن

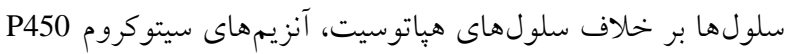

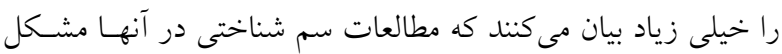
است. 'البته موفقيتهايى با توليد سلولهاى كارديوسيت از آها بدست آمده است.

\section{سيستمهاى اتوماتيك كثت}

جناين روش از سيستمهــاى اتوماتيـى كشـت سـلولى بــراى غربالكرى و مشاهده شـرايط متنـوع تمـايز در خاهـكهـاى متنـوع استفاده شده است كه جداسازى آنها نيز بصـورت اتوماتيـك فـراهم

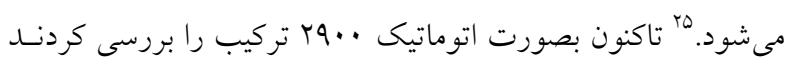
كه بر روى تكثير خودى و تمايز در HES سـلهـ

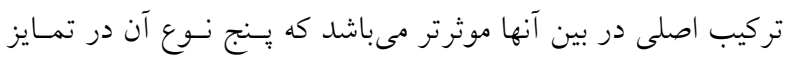
نقش دارند كه عبارتنـــ از : رتينوئيـى اسـيد، ســاخلين، سـايمرين، سارمنتوزنين كه كاملا در تمايز سلولها به رده ديخـر سـلولى مـوثر

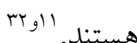




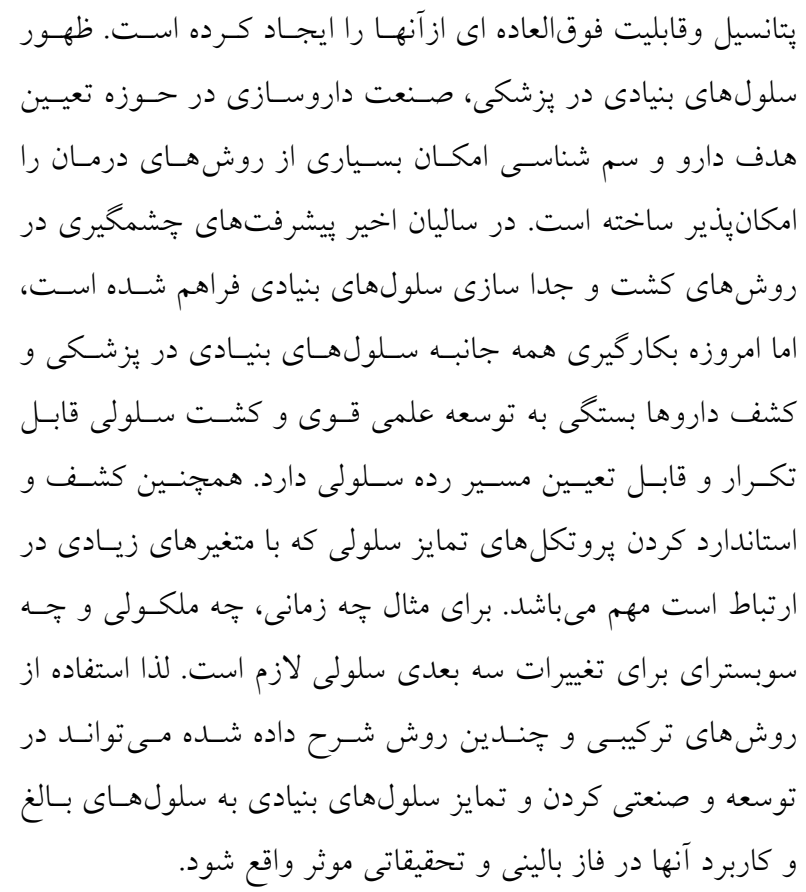

\section{References}

1. Gulotta LV, Chaudhury S, Wiznia D. Stem cells for augmenting tendon repair. Stem cells international. 2012; 291-431.

2. Améen C, Strehl R, Björquist P, Lindahl A, Hyllner J, Sartipy P. Human embryonic stem cells: Current technologies and emerging industrial applications. Critical Reviews in Oncology/Hematology. 2008;65(1):54-80.

3. Baraniak PR, McDevitt TC. Stem cell paracrine actions and tissue regeneration. Regenerative medicine. 2010 Jan;5(1):121-43.

4. Buecker C, Geijsen N. Different flavors of pluripotency, molecular mechanisms, and practical implications. Cell Stem Cell. 2010 Nov 5;7(5):559-64.

5. Van der Jeught M, Taelman J, Duggal G, Ghimire S, Lierman S, Chuva de Sousa Lopes SM, et al. Application Of Small Molecules Favoring Naive Pluripotency during Human Embryonic Stem Cell Derivation. Cell Reprogram. 2015 Jun;17(3):170-80.

6. Guilak F, Cohen DM, Estes BT, Gimble JM, Liedtke W, Chen CS. Control of Stem Cell Fate by Physical Interactions with the Extracellular Matrix. Cell Stem Cell. 2009;5(1):17-26.

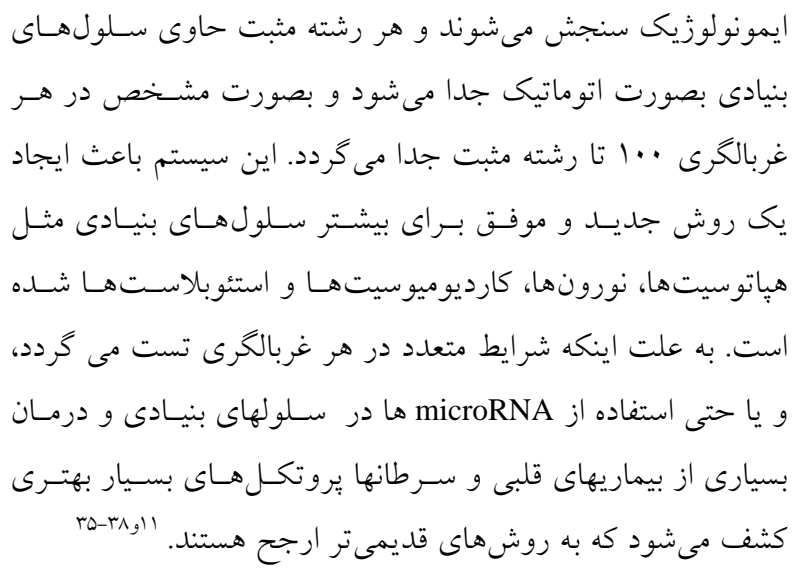

7. Yin Z, Chen X, Chen JL, Ouyang HW. Stem cells for tendon tissue engineering and regeneration. Expert opinion on biological therapy. 2010 May;10(5):689-700.

8. Chen Y, Lai D. Pluripotent states of human embryonic stem cells. Cell Reprogram. 2015 Feb;17(1):1-6.

9. Cezar GG. Can human embryonic stem cells contribute to the discovery of safer and more effective drugs? Current Opinion in Chemical Biology. 2007;11(4):405-9.

10. Jensen J, Hyllner J, Bjorquist P. Human embryonic stem cell technologies and drug discovery. Journal of cellular physiology. 2009 Jun;219(3):513-9.

11. Hook LA. Stem cell technology for drug discovery and development. Drug Discov Today. 2012 Apr;17(7-8):33642.

12. Pouton CW, Haynes JM. Pharmaceutical applications of embryonic stem cells. Adv Drug Deliv Rev. 2005 Dec 12;57(13):1918-34.

13. Merkle FT, Alvarez-Buylla A. Neural stem cells in mammalian development. Current Opinion in Cell Biology. 2006;18(6):704-9.

14. Inoue $\mathrm{H}$, Yamanaka $\mathrm{S}$. The use of induced pluripotent stem cells in drug development. Clin Pharmacol Ther. 2011 May;89(5):655-61. 
15. Chamling X, Sluch VM, Zack DJ. The Potential of Human Stem Cells for the Study and Treatment of Glaucoma. Investigative ophthalmology \& visual science. 2016 Apr 1;57(5):ORSFi1-6.

16. Lister R, Pelizzola M, Kida YS, Hawkins RD, Nery JR, Hon G, et al. Hotspots of aberrant epigenomic reprogramming in human induced pluripotent stem cells. Nature. 2011;471(7336):68-73.

17. Pouton CW, Haynes JM. Embryonic stem cells as a source of models for drug discovery. Nat Rev Drug Discov. 2007 Aug;6(8):605-16.

18. Takahashi K, Yamanaka S. Induction of Pluripotent Stem Cells from Mouse Embryonic and Adult Fibroblast Cultures by Defined Factors. Cell. 2006;126(4):663-76.

19. Van der Jeught M, O'Leary T, Duggal G, De Sutter P, Chuva de Sousa Lopes S, Heindryckx B. The post-inner cell mass intermediate: implications for stem cell biology and assisted reproductive technology. Hum Reprod Update. 2015 Sep-Oct;21(5):616-26.

20. Chun YW, Voyles DE, Rath R, Hofmeister LH, Boire TC, Wilcox H, et al. Differential responses of induced pluripotent stem cell-derived cardiomyocytes to anisotropic strain depends on disease status. J Biomech. 2015 Nov 5;48(14):3890-6.

21. Mansouri F. The role of the clinical and molecular assays in prostate cancer detection. Asian Journal of Pharmaceutical and Clinical Research. 2017;10(6):11-5.

22. Mojarrad M, Momeny M, Mansouri F, Abdolazimi Y, Tabrizi MH, Ghaffari SH, et al. Autocrine human growth hormone expression leads to resistance of MCF-7 cells to tamoxifen. Med Oncol. 2010 Jun;27(2):474-80.

23. Trosko JE, Chang CC. Factors to consider in the use of stem cells for pharmaceutic drug development and for chemical safety assessment. Toxicology. 2010 Mar 30;270(1):18-34.

24. Welling M, Geijsen N. Uncovering the true identity of naive pluripotent stem cells. Trends Cell Biol. 2013 Sep;23(9):442-8.

25. Chen A, Ting S, Seow J, Reuveny S, Oh S. Considerations in designing systems for large scale production of human cardiomyocytes from pluripotent stem cells. Stem cell research \& therapy. 2014;5(1):12.

26. Sartipy P, Björquist P, Strehl R, Hyllner J. The application of human embryonic stem cell technologies to drug discovery. Drug Discovery Today. 2007;12(1718):688-99.
27. Ebert AD, Svendsen CN. Human stem cells and drug screening: opportunities and challenges. Nat Rev Drug Discov. 2010 May;9(5):367-72.

28. Erickson-Miller CL, DeLorme E, Tian S-S, Hopson CB, Stark K, Giampa L, et al. Discovery and characterization of a selective, nonpeptidyl thrombopoietin receptor agonist. Experimental Hematology. 2005;33(1):85-93.

29. Reilly GC, Engler AJ. Intrinsic extracellular matrix properties regulate stem cell differentiation. Journal of Biomechanics. 2010;43(1):55-62.

30. Azarin SM, Palecek SP. Development of scalable culture systems for human embryonic stem cells. Biochemical Engineering Journal. 2010;48(3):378-84.

31. Lin C, Ballinger KR, Khetani SR. The application of engineered liver tissues for novel drug discovery. Expert Opin Drug Discov. 2015 May;10(5):519-40.

32. Miryounesi M, Nayernia K, Diantpour M, Mansouri F, Modarressi M H. Co-culture of mouse embryonic stem cells with sertoli cells promote in vitro generation of germ cells. IJBMS. 2012.

33. Sun B, Yu W, Wang F, Song W, Jin H, Sun Y. Effects of group culture on the development of discarded human embryos and the construction of human embryonic stem cell lines. Journal of assisted reproduction and genetics. 2014 Oct;31(10):1369-76.

34. Khetani SR, Berger DR, Ballinger KR, Davidson MD, Lin C, Ware BR. Microengineered liver tissues for drug testing. J Lab Autom. 2015 Jun;20(3):216-50.

35. Gholikhani-Darbroud R, Khaki-Khatibi F, Mansouri F, et al. Decreased circulatory microRNA-4478 as a specific biomarker for diagnosing non-ST-segment elevation myocardial infarction (NSTEMI) and its association with soluble leptin receptor. Bratisl Lek Listy. 2017;118(11):684-90.

36. Ashtiani Z, Mansouri F. Overview of Medical Genetics and Common disorders of hearing and speech. Tehran: Nashr Da; 2015.[In Persian]

37. Ai J, Zhang R, Li Y, Pu J, Lu Y, Jiao J, et al. Circulating microRNA-1 as a potential novel biomarker for acute myocardial infarction. Biochem Biophys Res Commun. 2010 Jan 1;391(1):73-7.

38. Mansouri F, Farzaneh P, Fazeli A. Collection and culture of dental pulp stem cell, Medical genetics congress, Tehran, IRAN,2013. 